\title{
An Assessment on the Development of the Nationwide Solid Waste-To-Energy Potential Model in the Philippines
}

\author{
Ronald Allan $\mathrm{Co}^{1, *}$, and Enrico Paringit ${ }^{2}$ \\ ${ }^{1}$ Energy Engineering Graduate Program, University of the Philippines, Melchor Hall, Osmeña \\ Avenue, Diliman, Quezon City, National Capital Region, 1101, Republic of the Philippines. \\ ${ }^{2}$ Geodetic Engineering Department, University of the Philippines, Melchor Hall, Osmeña Avenue, \\ Diliman, Quezon City, National Capital Region, 1101, Republic of the Philippines.
}

\begin{abstract}
Solid waste biomass contains a significant amount of carbohydrates and other combustible chemical compounds that have potential as an alternative energy source. In this paper, the synthesis of biomass energy potential assessment from solid waste and the development of a model equation was presented, in order to utilize as assessment tools for the Philippine local government units, most especially the established sanitary landfills and waste-to-energy technologies and facilities that are soon-to-be installed. Data for the said model equation was obtained from various Philippine government agencies, such as the Department of Energy, Department of Environment and Natural Resources, and others. In order to accumulate those in the model, numerous concepts are applied, such as parameterization and others. Furthermore, a time-series study is subjected to analysis, in order to forecast of the biomass energy. Moreover, the biomass energy potential from the rest of the Philippine archipelago may be further evaluated with the use of the proposed model equation.
\end{abstract}

Keywords: Biomass, energy model, renewable energy, waste to energy assessment.

\section{Introduction}

Solid municipal waste is a growing problem in the United States and the rest of the world. For years, the generation of Municipal Solid Waste (MSW) in large countries, particularly the United States, grew very rapidly from almost one and half times. Much of this increase was due to population growth, but the rate of solid waste generation per person. Landfill sites are rapidly being filled and the availability of new sites is limited, especially near cities. In addition to the problem of site availability, there are problems of groundwater contamination, odor, disease, toxic chemicals, and escaping methane [1].

The average heat content of MSW is about $4300 \mathrm{BTU} \mathrm{lb}^{-1}\left(10000 \mathrm{~kJ} \mathrm{~kg}^{-1}\right)$, about a third that of good coal. While disposing of the waste is the primary goal, sufficient heat can be released by burning waste to make a worthwhile contribution to steam-generated electric

*Corresponding author: engr.ra.co7272@gmail.com 
power. The waste incinerators must be designed to dry the waste as well to burn it. This is accomplished by injecting enough air into the firebox for complete burnout. The hot exhaust gases must be cleaned by electrostatic precipitators or baghouses to remove particulates, combined with wet or dry scrubbers to remove acid gases. The incinerators are designed differently depending on whether they are intended for mass burning of the normal mix of municipal wastes, or for incinerating wastes that are separated prior to burning [2].

According to the study conducted by [3], the waste-to-energy facilities are very capitalintensive, and many municipalities find it difficult to make the necessary investment. There has been a trend toward private rather than public ownership. Most of the existing facilities generate electricity alone, and the rest generate steam or combined steam and electricity. While the energy derived from MSW is far from negligible, the contribution of the recycling program to a reduction of the solid waste going into landfills is probably more significant. As reported by various media with regards to the Payatas tragedy [4], a mountain-full of garbage was collapsed at the Payatas dumpsite in Quezon City. As a result, numerous shanties and communities living near were trapped and buried alive.

Another report [5], the Quezon City government was hastening to find a new place to dump the more than $438000 \mathrm{t}$ of garbage the city that generated every year, which was equivalent to 146000 dump trucks.

Several Philippine television programs, like Reporter's Notebook [6], tackled San Juan River in Mandaluyong City, Philippines, as one of the polluted bodies of water around Metro Manila. Numerous garbage bags were floating across the river that is eventually crossed in the Pasig River. Similarly, another documentary program, I-Witness [7], upon exploring the Freedom Island, an oasis of lush mangroves on the shores of Manila Bay and the famous last wild space in our concrete jungle of a metropolis, by the program host, Mr. Howie Severino, and his team, they have encountered a sea of garbage that pushed against the mangroves' edge, that composes most are plastics. The team then began their investigation into how such material of convenience has become a scourge of the earth and a threat to life.

Based on the Energy Data Statistics of the Department of Energy [8], there are no further studies conducted and assessed with regards to the feasibility of the garbage as a fuel source. Furthermore, there is the potential of recovering waste heat released by the incinerator or pyrolyzer and utilizing its thermal energy to compensate for energy requirements upon using certain garbage as a fuel source, particularly on combustible materials (e.g., supplying electricity, or for lighting and transport purposes in the communities living nearby open dumpsites and sanitary landfills). Thus, this study is conducted to have an initial feasibility application of the resource assessment on municipal solid waste turning energy in the Philippine setting. This is where the researcher has conducted further studies with this type of potential energy source.

Similar to the study [9], Boiler 1, found inside the Coal-Fired Boiler House of a local food snack manufacturing company, was recommended by the Engineering and Maintenance Manager to the researcher as pre-ORC (Organic Rankine Cycle) source equipment. Furthermore, there was the potential of recovering waste heat released by the boiler and utilizing its thermal energy to compensate for energy requirements in other parts of the plant, (e.g., supplying electricity to the pumps inside the beverage manufacturing department, or for lighting and transport purposes in the wastewater treatment facility, and others).

In the present study, the parameterization technique is used in the development and formulation of the municipal solid waste-to-energy model equation. Parameterization is the specification of a curve, surface, and so on., using one or more variables that are allowed to take on values in a given specified range. It is widely used in mapping of curves in two- 
(2D) and three-dimensional (3D) plotting, e.g. conducting study is discrete exponential models in statistics, as mentioned in [10]; with the use of iso-geometric analysis on domains that contain singularities [11]; and, using parameterization in studying timefrequency analysis [12]. A parameterization-based model equation is used to evaluate the nationwide solid waste-to-energy potentials.

\section{Methodology}

\subsection{The proposed model equation (the Co equation)}

\subsubsection{The Data Gathering Process}

Figure 1 represents the data gathering process for this study. For the waste types, recyclable and residual wastes are taken only to be considered. Each waste element stream is determined as follows. Shown in Equation (1) is the solid waste-to-energy potential terms based on the recyclable wastes. Meanwhile, presented in Figure 2 is the solid waste-toenergy potential terms based on the residual wastes. Some information is obtained from [13] in Equation (1) and Equation (2).

$$
\begin{gathered}
E_{R C}=f\left(G, p, a, e, w_{R C}, N C V_{R C}\right) \\
E_{R S}=f\left(G, p, a, e, w_{R S}, N C V_{R S}\right)
\end{gathered}
$$

where: $\mathrm{E}=$ solid waste-to-energy terms for each local government unit (LGU) $\left(\mathrm{kJ} \mathrm{yr}^{-1}\right)$, $\mathrm{G}=$ waste collection rate $\left(\mathrm{kg}_{\text {capita }} \mathrm{yr}^{-1}\right), \mathrm{p}=$ cluster of people living for each LGU or population for each LGU (capita), a = average land consumption ratio $\left(\mathrm{km}^{2} \mathrm{~km}^{-2}\right), \mathrm{w}=$ average waste composition ratio $\left(\mathrm{kg} \mathrm{kg}^{-1}\right)$, and $\mathrm{NCV}=$ average net calorific value for each solid waste type $\left(\mathrm{kJ} \mathrm{kg}^{-1}\right)$. Subscripts $\mathrm{RC}$ and $\mathrm{RS}=$ represents the recyclable and residual wastes, respectively.

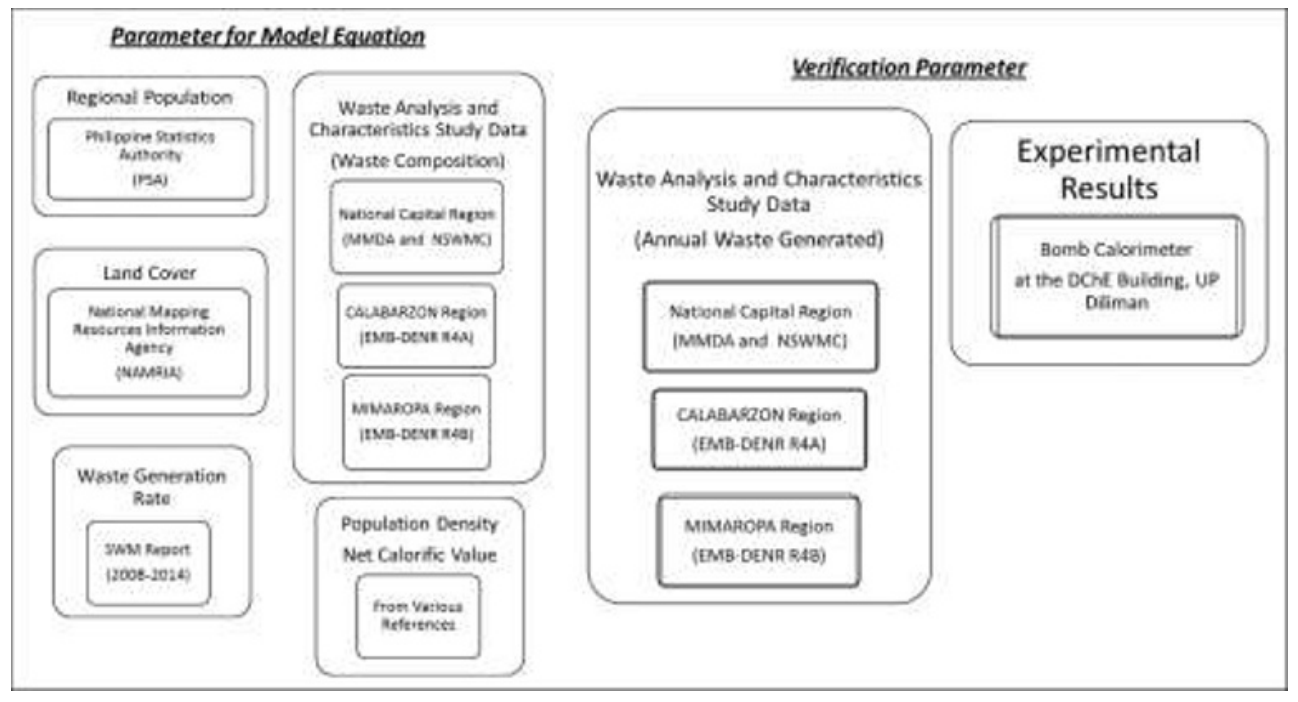

Fig. 1. The data gathering process 


\subsubsection{The development of the Co Equation}

By applying the material and energy balance concepts, dimensional analysis method [14, 15], parameterization technique, and others to those previous equations, namely Equation 1 and Equation (2). The magnitude of annual solid waste-to-energy potential per LGU becomes, in Equation (3).

$$
E=R \sqrt{A^{2}+C^{2}}
$$

where: $\mathrm{E}=$ estimated total solid waste-to-energy potential per local government unit (LGU) $(\mathrm{kW}) ; \mathrm{R}=$ evaluated constant term per LGU $\left(\mathrm{kg} \mathrm{yr}^{-1}\right), \mathrm{A}$ and $\mathrm{C}=$ the energy potential parameters based from recyclable, and residual waste terms $\left(\mathrm{kJ} \mathrm{kg}^{-1}\right)$, respectively.

Equation (3) is the parameterized model equation. This model equation is named as the Co-Equation, in due respect to the dedication of the author in conceptualizing the model equation.

\section{Result and discussion}

\subsection{The decadal solid waste-to-energy potential trend for llocos Norte (Province from Region 1)}

\subsubsection{National capital region}

Figure 2 shows the decadal solid waste-to-energy forecast trend in the National Capital Region. From the data gathered from various Philippine government agencies, like the population data (Region 1) from Philippine Statistics Authority (PSA) [17] and the WACS Data from Environmental Management Bureau-Department of Environment and Natural Resources (EMB-DENR) [16] and Metropolitan Manila Development Authority (MMDA) [18] and others, they are carefully executed, analyzed, and evaluation to the Equation (3). As a result, the estimated solid waste-to-energy potential as of 2028 for the National Capital Region is around $2.79 \times 10^{9} \mathrm{MW} \mathrm{h} \mathrm{yr}^{-1}$. Moreover, the solid waste-to-energy potential from the rest of the LGUs found in the Philippine archipelago may be further evaluated with the use of the Co Equation.

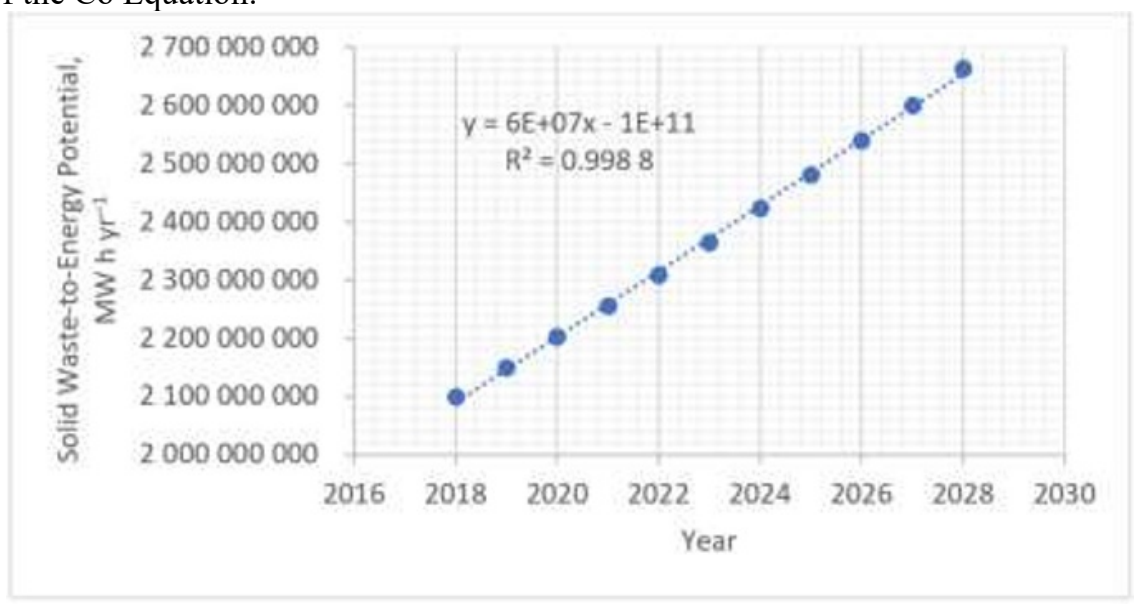

Fig. 2. The decadal solid waste-to-energy potential forecast trend for the National Capital Region 


\subsubsection{CALABARZON Region}

Figure 3 shows the decadal solid waste-to-energy forecast trend in the CALABARZON Region. As a result, the estimated solid waste-to-energy potential as of 2028 for the CALABARZON Region is around $9.00 \times 10^{9} \mathrm{MW} \mathrm{h} \mathrm{yr}^{-1}$.

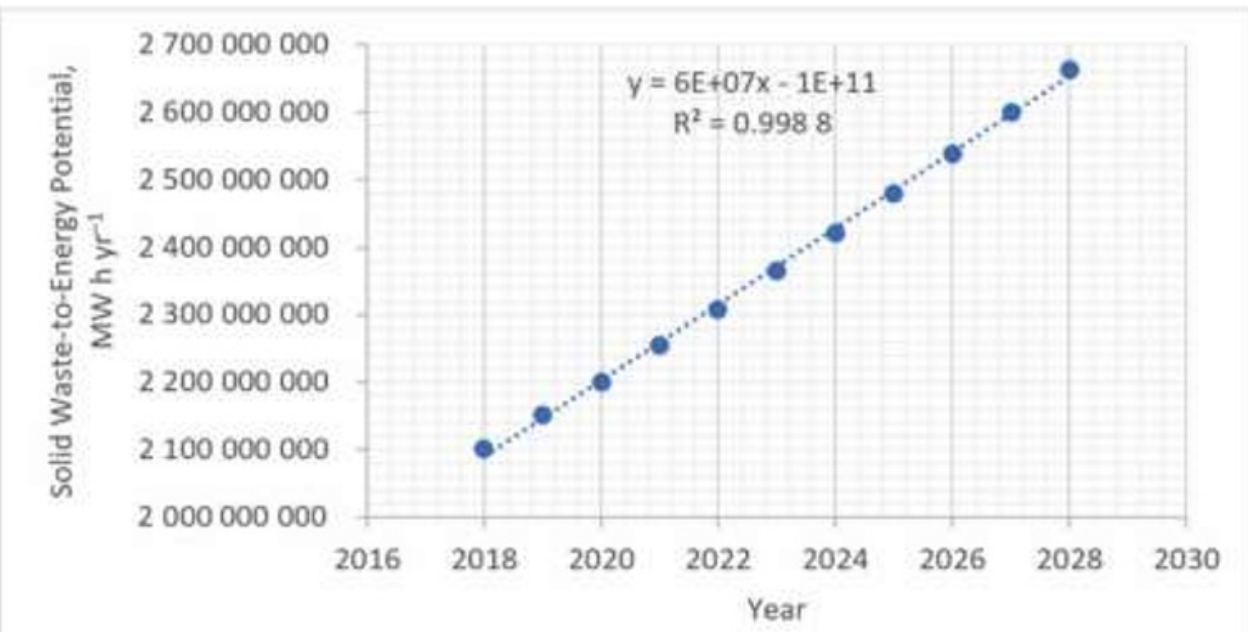

Fig. 3. The decadal solid waste-to-energy potential forecast trend for the CALABARZON Region

\subsubsection{MIMAROPA Region}

Figure 4 shows the decadal solid waste-to-energy forecast trend in the MIMAROPA Region (Region IV-B). As a result, the estimated solid waste-to-energy potential as of 2028 for the MIMAROPA Region is around $5.40 \times 10^{5} \mathrm{MW} \mathrm{h} \mathrm{yr}^{-1}$.

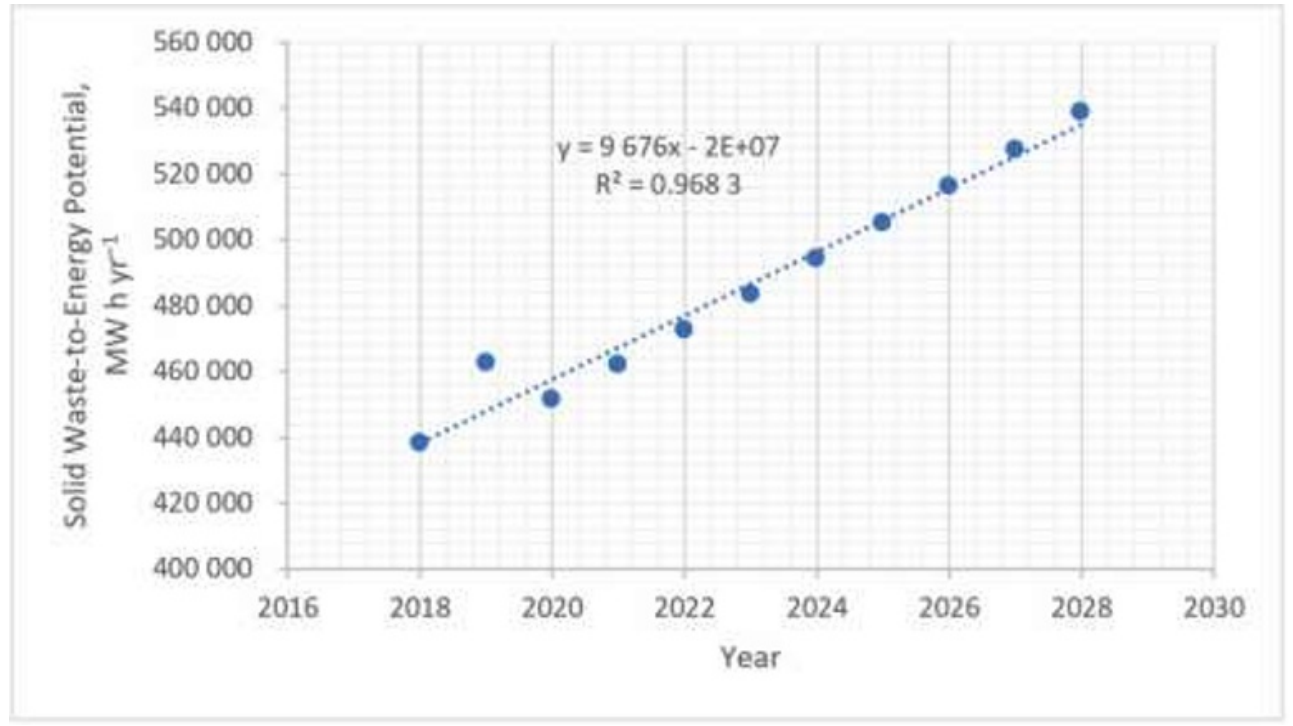

Fig. 4. The decadal solid waste-to-energy potential forecast trend for the MIMAROPA Region 


\section{Conclusion}

In this study, the Co Equation is being used to assess the solid waste-to-energy potential of three (3) of the central regions found in the Island of Luzon, Republic of the Philippines, namely the National Capital Region, CALABARZON Regions, and MIMAROPA Region. The estimated forecast trend solid waste-to-energy values for the year 2028 is $2.79 \times 10^{9}$ $\mathrm{MW} \mathrm{h} \mathrm{yr}{ }^{-1}, 9.00 \times 10^{9} \mathrm{MW} \mathrm{h} \mathrm{yr}^{-1}$, and $5.40 \times 10^{5} \mathrm{MW} \mathrm{h} \mathrm{yr}^{-1}$, respectively. Furthermore, this Equation can be utilized in the regional assessment for the rest of the regions of Luzon and even in Visayas and Mindanao regions as well.

The corresponding author would like to extend the sincere gratitude to (i) Dr. Enrico C. Paringit, (Adviser) for the numerous supports in this study with his expertise in the field and for his patience, motivation, enthusiasm, and immense knowledge is much appreciated, and his guidance helped me a lot with the research and writing of this dissertation; (ii) to Engineering Research and Development for Technology (ERDT) scholarship for the financial support of this study; (iii) to various Philippine government agencies, such as Philippine Statistics Authority (PSA), Department of Energy (DOE), Environmental Management Bureau-Department of Environment and Natural Resources (EMBDENR), Metropolitan Manila Development Authority (MMDA), and others for providing the data needed for the development of the model equation.

\section{References}

1. R.A. Ristinen. Energy and the environment. 3rd ed. John Wiley and Sons, Inc, USA (2016). pp. 135-136.

https://www.wiley.com/en-us/Energy+and+the+Environment $\% 2 \mathrm{C}+3 \mathrm{rd}+$ Edition+-p9781119179238

2. D. Premakumara, S. Menikpura, R. Singh, M. Hengesbaugh, A. Magalang, E. Ildefonso, et al. Waste Mgt, 80:397-405(2018).

https://dl.uswr.ac.ir/bitstream/Hannan/95155/1/2018\%20WasteManagement $\% 20 \mathrm{Volu}$ me $\% 2080 \% 20$ October $\% 20 \% 2844 \% 29 . \mathrm{pdf}$

3. G. Sapuay. Proc. Envi. Sci., 35:464-473(2016).

https://www.sciencedirect.com/science/article/pii/S1878029616301190

4. B. Sison, C. Felipe. Payatas tragedy: One year after [Online] from https://www.philstar.com/headlines/2001/07/10/91819/payatas-tragedy-one-year-after (2001). [Accessed on 20 May 2019].

5. P. Rañada. Time ticking for Payatas landfill. [Online] from https://www.rappler.com/nation/52307-payatas-landfill-end-contract (2014). [Accessed on 20 May 2019].

6. Reporter's Notebook. Ilog at estero na tambak ng basura, tinungo ng [Basura in the city (Garbage in the city)]. [Online] from https://www.youtube.com/watch? $\mathrm{v}=$ QVmuS26YjQ (2018). [Accessed on 27 May 2019]. [in Tagalog].

7. I-Witness. Plastic republic. [Online] from https://www.youtube.com/watch?v=y2AYVKaiYQc (2018). [Accessed on 27 May 2019]. [in Tagalog].

8. Department of Energy Republic of the Philippines. Energy data and statistics. [Online] from

https://www.doe.gov.ph/sites/default/files/pdf/energy statistics/02 2017 power_statist ics_as_of 30 april_2018_capacity_per_plant_type2.pdf (2017). [Accessed on 28 May 2019].

9. R.A.S. Co, S.A. Gilos, K.B. Aviso, M.A.B. Promentilla. An analytic hierarchy process (AHP) approach for the selection of working fluid in an organic rankine cycle (ORC) system. Paper presented in DLSU Research Congress (Manila, Philippines, 2015). 
https://www.dlsu.edu.ph/wp-content/uploads/pdf/conferences/research-congressproceedings/2015/SEE/029-SEE_Co_RAS.pdf

10. C. Améndola, N. Bliss, I. Burke, C.R. Gibbons, M. Helmer, S. Hosten, et al. Jour. of Symb. Compu., 92:222-242(2018) https://www.researchgate.net/publication/314283080 The Maximum_Likelihood_Deg ree of Toric Varieties.

11. A. Qarariyah, F. Deng, T. Yang, Y. Liu, and J. Deng. Jour. of Compu. and App. Math., 350:353-371(2019). https://www.sciencedirect.com/science/article/abs/pii/S0377042718306198

12. Y. Yang, Z. Peng, W. Zhang, G. Meng. Mech. Sys. \& Signal Proc., 119, 182221(2018).

https://www.sciencedirect.com/science/article/abs/pii/S088832701830445X\#!

13. EcoGov Project 2011. Waste analysis and characterization study (WACS)-A manual. USAID and Philippine Environmental Governance Project (EcoGov), Philippines (2011). pp. 1-20, 100-120.

http://faspselib.denr.gov.ph/sites/default/files//Publication\%20Files/Waste\%20Analysi s\%20and\%20Characterization\%20Study A\%20Manual.pdf

14. D.M. Himmelblau, J.B. Riggs. Basic principles and calculations in chemical engineering. 8th ed. Pearson Education, Inc, USA (2012). pp. 100-120. https://www.pearson.com/us/higher-education/program/Himmelblau-Basic-Principlesand-Calculations-in-Chemical-Engineering-8th-Edition/PGM86406.html

15. R.M. Felder, R.W. Rousseau. Elementary principles of chemical processes. 3rd ed. John Wiley and Sons, Inc., USA (2005). pp. 30-40, 140-150. https://books.google.co.id/books?id=koSvQgAACAAJ\&dq

16. Environmental Management Bureau-Department of Environment and Natural Resources (EMB-DENR). Report of the waste analysis and characterization study of region 1 [Online] from https://emb.gov.ph/wp-content/uploads/2018/09/3-Solid-Waste1.8.pdf (2018). [Accessed on 27 May 2019]

17. Republic of the Philippines: PSA. National census and statistics (region 1 - Ilocos Region) [Online] from http://www.psa.gov.ph/content/population-region-i-ilocosregion-based-2015-census-population (2016). [Accessed on 27 May 2019]

18. Metropolitan Manila Development Authority (MMDA). Solid waste management report of 2018 [Online] from http://www.mmda.gov.ph/images/Home/Infomercial2018.pdf (2018). [Accessed on 27 May 2019] 